\title{
Indoor Air Pollution in Rural Settings in Plateau State Nigeria
}

\section{Adah O.S, Shown L.D, Yusuff O.E, Envuladu E.A, Banwat M.E, Dhakin A, Chingle M.P, Audu S, Bupwatda P.W}

\author{
Department of Community Medicine Jos University Teaching Hospital, Jos, Plateau State, Nigeria.
}

Coorespondence: Dr. S.Adah, Department of Community Medicine, Jos University teaching Hospital.

\begin{abstract}
Background: Indoor air pollution consists of toxic gases or particles that can harm people's health. ${ }^{\text {IT These }}$ pollutants can build up rapidly indoors to levels much higher than those usually found outdoors. This study therefore seeks to determine the magnitude of indoor pollution in Plateau State and its effects.

Methods: The study design used was cross sectional. Using the simple random technique, Plateau State was selected by balloting and likewise the two local governments and the districts, respectively.

A sample size of 500 was used according to a study carried out in Delta State, Nigeria, where 98\% of the population uses solid fuel as a source of cooking and heating.

Results: Majority of the respondents, (47.40\%) use firewood as fuel for cooking and minority, (1.00\%), cooking gas. Most (50.60\%) are farmers Three hundred and fifty eight (71.60\%), of the respondents cough and majority, (78.06\%), use firewood as a source of fuel. Majority, four hundred and sixty two (92.40\%) of the respondents did not experience headaches with fuel for cooking and thirty four, (6.80\%) of the respondents did not have red eyes with the use of the various sources offuel for cooking.

Conclusion: Indoor air pollution is a major public health hazard, especially in the rural settings. It may be responsible for a similar proportion of the global burden of disease and it is necessary to keep in mind the close relationship between poverty and dependence on polluting fuels. Socioeconomic development should be the core effort to achieve healthier household environments.
\end{abstract}

Key words: Indoor Air Pollution, Rural Settings

\section{Introduction}

Indoor air pollution consists of toxic gases or particles that can harm people's health. ${ }^{1}$ These pollutants can build up rapidly indoors to levels much higher than those usually found outdoors.

The quality of air in homes can impact the health of those living in it. Most people are aware that outdoor air pollution can significantly affect people's health, but Environmental Protection Agency studies have shown that levels of air pollutants indoors may be anywhere from 2 to 5 times greater than outdoors, and in some cases more than 100 times greater. ${ }^{2}$

Indoor air pollution can be a real concern because people can spend as much as $90 \%$ of their time indoors, and much of that time is in their homes. ${ }^{2}$ As they strive for greater energy efficiency with better insulation, their increasingly air-tight homes are exacerbating the problem of indoor air pollution.

In developing countries, a substantial part of the population relies on the use of solid fuels for cooking and heating. ${ }^{3}$ These fuels include wood, crop residue, animal dung and coal. ${ }^{3}$ This practice is of significant public health importance. Among environmental risk factors, indoor air pollution resulting from the combustion of solid fuels may be one of the leading contributors to the global burden of disease in such developing countries. ${ }^{4}$ Indoor air pollution is responsible for $2.7 \%$ of the global burden of disease. ${ }^{5}$

Cooking and heating with solid fuels on open fires or traditional stoves results in high levels of indoor air pollution. Indoor smoke contains a range of health-damaging pollutants, such as small particles and carbon monoxide, and particulate pollution levels may be 20 times higher than accepted guideline values. $^{6}$

Tobacco smoke is one indoor pollutant that is easy to reduce. Second-hand tobacco smoke holds a raft of noxious compounds from carbon monoxide to formaldehyde. ${ }^{7}$ Second-hand smoke can have a major impact on fetal development and can lead to heart disease and even lung cancer in non-smokers.

The health or quality level of the air in a home is determined by how much and how often pollution is getting into the air. For example, if you have a properly adjusted gas stove, it will emit significantly less carbon monoxide than one that is not properly adjusted. Also, good ventilation contributes to improving air quality: 
The effects of indoor air pollutants range from short-term effects such as eye and throat irritation to long-term effects - respiratory disease and cancer. Exposure to high levels of some pollutants, such as carbon monoxide, a colorless and odorless gas which is a common combustion product, can produce dizziness, headaches, nausea and coughing, effects that are often misdiagnosed as the flu. ${ }^{8}$ If the blood concentration gets high enough, it can result in immediate death. Some indoor pollutants can magnify the effects of other indoor pollutants.

This study therefore seeks to determine the magnitude of indoor pollution in Plateau State and its effects.

\section{Methods}

This study was carried out in July 2008 in Plateau State, using six districts in two Local Government Areas. Plateau State is located in the North Central Region of Nigeria, with a population of $3,178.712$, according to the 2006 National Population Census. ${ }^{9}$ The terrain is rocky and the temperature is cool and accommodating, especially at this time of the rainy season.

The two local governments used were Mangu and Pankshin Local Governments. They have populations of 314,109 and 204,109 respectfully ${ }^{10}$. Both share the same geographical and climatic conditions of the state and Pankshin is considered the coldest part of the state. Inhabitants of both states are predominantly farmers and traders. The districts used in Mangu include Ampang West, Jipal and Kerang and in Pankshin, Chip, Jing and Kagu.

The study design used was cross sectional. Using the simple random technique, Plateau State was selected by balloting and likewise the two local governments and the districts, respectively.

A sample size of 500 was used according to a study carried out in Delta State, Nigeria, where $98 \%$ of the population uses solid fuel as a source of cooking and heating. ${ }^{11}$

Interviewer administered questionnaires were administered to the illiterate and for the literate it was self administered. The data was analyzed using Epi info version 3.3.2 to test for significance using Chi Square, a test of proportions.

\section{Results}

Majority of the respondents, two hundred and thirty seven $(47.40 \%)$ use firewood as fuel for cooking. Minority of the respondents, five $(1.00 \%)$, use cooking gas. Table 1
Most of the respondents, two hundred and fifty six $(50.60 \%)$ are farmers. Table2

Ninety six, $(40.85 \%)$ of the respondents who are farmers use charcoal as their fuel for cooking. Majority of the hunters, a hundred, (50.51\%) use firewood as their source of fuel. Thirty two, $(65.31 \%)$ of the teachers use firewood as fuel for cooking.Table3

Table 1: Fuel for Cooking

\begin{tabular}{lll}
\hline Fuel & Frequency & Percent \\
\hline Cooking Gas & 5 & $1.00 \%$ \\
Kerosene & 159 & $31.80 \%$ \\
Charcoal & 98 & $19.60 \%$ \\
Coal & 1 & $0.20 \%$ \\
Firewood & 237 & $47.40 \%$ \\
\hline Total & $\mathbf{5 0 0}$ & $\mathbf{1 0 0 . 0 0} \%$ \\
\hline
\end{tabular}

Table 2: Frequency of Occupation

\begin{tabular}{lll}
\hline Occupation & Frequency & Percent \\
\hline Farming & 253 & $50.60 .00 \%$ \\
Hunting & 127 & $25.40 .00 \%$ \\
Teaching & 120 & $47.43 .00 \%$ \\
\hline Total & $\mathbf{5 0 0}$ & $\mathbf{1 0 0 . 0 0 \%}$ \\
\hline
\end{tabular}

Table 3: Occupation and Fuel for Cooking

Fuel For Cooking

\begin{tabular}{|c|c|c|c|c|c|c|}
\hline Occupation & Coal & Charcoal & Firewood & Cow Dung & $\begin{array}{l}\text { Cooking } \\
\text { Gas }\end{array}$ & Total \\
\hline Farming & $\begin{array}{l}1(0.003953 \\
\%)\end{array}$ & $\begin{array}{l}96(40.85 \% \\
)\end{array}$ & $\begin{array}{l}88(34.78 \% \\
)\end{array}$ & $67(26.48 \%)$ & $\begin{array}{l}1(0.003953 \\
\%)\end{array}$ & $\begin{array}{l}253.0 \\
0\end{array}$ \\
\hline Hunting & $70(35.35 \%)$ & $3(1.52 \%)$ & $\begin{array}{l}100(50.51 \\
\%)\end{array}$ & $23(11.62 \%)$ & $2(1.01 \%)$ & 198 \\
\hline Teaching & $10(20.41 \%)$ & $1(2.04 \%)$ & $32(65.31)$ & $4(8.16 \%)$ & $2(4.08 \%)$ & 49 \\
\hline TOTAL & $81(16.20 \%$ & $\begin{array}{l}100(20.00 \\
\%)\end{array}$ & $\begin{array}{l}220(44.00 \\
\%)\end{array}$ & $94(19.20 \%)$ & $5(1.00 \%)$ & 500 \\
\hline
\end{tabular}

Table 4: Fuel for Cooking and Coughing Coughing

\begin{tabular}{llll}
\hline Fuel for Cooking & Yes & No & Total \\
\hline Cooking Gas & $2(40 \%)$ & $3(60 \%)$ & 5 \\
Kerosene & $109(68.55 \%)$ & $50(31.45)$ & 159 \\
Charcoal & $61(62.24 \%)$ & $37(37.76 \%)$ & 98 \\
Coal & $1(100 \%)$ & $0(0 \%)$ & 1 \\
Firewood & $185(78.06 \%)$ & $52(21.94 \%)$ & 237 \\
\hline Total & $\mathbf{3 5 8}(71.60 \%)$ & $\mathbf{1 4 2 ( 2 8 . 4 0 \% )}$ & $\mathbf{5 0 0}$ \\
\hline \multicolumn{1}{r}{$\mathrm{X}^{2}=12.66$} & $\mathrm{P}=0.01$ & &
\end{tabular}

Table 5: Fuel for Cooking and Headache

\begin{tabular}{llll}
\multicolumn{4}{c}{ B Headache } \\
\hline Fuel for Cooking & Yes & No & Total \\
\hline Cooking Gas & $1(20 \%)$ & $4(80 \%)$ & 5 \\
Kerosene & $9(5.66 \%)$ & $150(94.34 \%)$ & 159 \\
Charcoal & $12(12.24 \%)$ & $86(87.76 \%)$ & 98 \\
Coal & $0(0.00 \%)$ & $1(100.00 \%)$ & 1 \\
Firewood & $16(6.75 \%)$ & $221(93.25 \%)$ & 237 \\
\hline Total & $\mathbf{3 8}(\mathbf{7 . 6 \% )}$ & $\mathbf{4 6 2}(\mathbf{9 2 . 4 0 \% )}$ & $\mathbf{5 0 0}$ \\
\hline $\mathrm{X}^{2}=5.28 \mathrm{P}=0.26$ & & &
\end{tabular}


Table 6: Fuel for Cooking and

Red Eye

\begin{tabular}{llll} 
Red Eye & \multicolumn{2}{c}{ Red Eye } \\
\hline Fuel for Cooking & Yes & No & Total \\
\hline Cooking Gas & $2(40.00 \%)$ & $3(60.00 \%)$ & 5 \\
Kerosene & $21(13.21 \%)$ & $138(86.79 \%)$ & 159 \\
Charcoal & $17(17.35 \%)$ & $81(82.65 \%)$ & 98 \\
Coal & $0(0.00 \%)$ & $1(100.00 \%)$ & 1 \\
Firewood & $33(13.92)$ & $204(86.08 \%)$ & 237 \\
\hline Total & $\mathbf{7 3 ( 1 4 . 6 0 \% )}$ & $\mathbf{4 2 7 ( 8 5 . 4 0 \% )}$ & $\mathbf{5 0 0}$ \\
\hline $\mathrm{X}^{2}=3.69 \mathrm{p}=0.45$ & & &
\end{tabular}

Table 7 : Fuel for Cooking and Sneezing

\begin{tabular}{llll}
\multicolumn{3}{c}{ Sneezing } \\
\hline Fuel for Cooking & Yes & No & Total \\
\hline Cooking Gas & $0(0.00 \%)$ & $5(100.00 \%)$ & 5 \\
Kerosene & $12(7.55 \%)$ & $147(92.45 \%)$ & 159 \\
Charcoal & $9(9.18 \%)$ & $89(90.82 \%)$ & 98 \\
Coal & $0(0.00 \%)$ & $1(100.00 \%)$ & 1 \\
Firewood & $13(5.49 \%)$ & $224(94.51 \%)$ & 237 \\
\hline Total & $\mathbf{3 4}(\mathbf{6 . 8 0} \%)$ & $\mathbf{4 6 6}(\mathbf{9 3 . 2 0} \%)$ & $\mathbf{5 0 0}$ \\
\hline
\end{tabular}

$\mathrm{X}^{2}=2.10 \quad \mathrm{p}=0.72$

\section{Discussion}

More than half of the world's populations rely on dung, wood, crop waste or coal to meet their most basic energy needs. Cooking and heating with such solid fuels on open fires or stoves without chimneys leads to indoor air pollution.

Approximately half the world's population and up to $90 \%$ of rural households in developing countries still rely on unprocessed biomass fuels in the form of wood, dung and crop residues. ${ }^{12}$

In this study, most of the respondents use traditional sources of fuel for cooking. Majority, $237(47.40 \%)$ use firewood. This is in keeping, though about $50 \%$ lower than that with a study carried out in Kathmandu, where around 85 per cent of the total population depend on such fuel. ${ }^{13}$

One respondent $(0.20 \%)$ use coal. This is lower than that $(3.00 \%)$ found in a study carried out in India. $^{14}$

One hundred and fifty nine $(31.80 \%)$ use kerosene as a fuel source. This is higher than that of a study conducted in Delta State, Nigeria $(9.00 \%){ }^{15}$

According to the 2004 assessment of the International Energy Agency, the number of people relying on biomass fuels such as wood, dung and agricultural residues, for cooking and heating will continue to rise.

Despite the magnitude of this growing problem, the health impacts of exposure to indoor air pollution have yet to become a central focus of research, development aid and policy-making. ${ }^{16}$

Indoor air pollution is one of the main causes of health hazards among the rural people and $20 \%$ of the population exposed to the smoke suffer from different complications. ${ }^{12}$ Seventy three $(14.60 \%)$ experienced red eyes from this study. This is a major complication of indoor air pollution. Three hundred and fifty eight $(71.60 \%)$ experienced the complication of coughing and thirty four $(6.80 \%)$ experienced sneezing. For the world as a whole, acute respiratory infection is the largest category, accounting for about $8.5 \%$ of the global burden. ${ }^{16}$ Various studies in developing countries have reported on the association between exposure to indoor air pollution and acute lower respiratory infections. ${ }^{17-20}$ In the Western Pacific, a study showed that $50 \%$ of deaths due to indoor air pollution were due to respiratory complications. ${ }^{16}$ Every year, indoor air pollution is responsible for the death of 1.6 million people. ${ }^{16}$

This study showed that the majority of respondents, four hundred and sixty two $(92.40 \%)$ did not experience the complication of headache. It was not statistically significant $(p=0.26)$ and may be due to chance.

References

1. Sapkota A, Gajalakshmi V, Jetly DH, Rowchodhury S, Dikshit RP, Brennan P, Hashibie M, Etal. Indoor Air Pollution From Solid Fuels and Risk of Hypopharyngeal/ Laryngeal and Lung Cancers: A Multicentric Case- Control Study From India. International Journal of Epidemiology 2008:37:321328.

2. Pau MJS. How to Fight Indoor Air Pollution. Available At airpollution.cfm.ntm. Last Accessed 30/06/2008.

3. Park E, Lee K.Particulate Exposure and Size Distribution From Wood Burning Stoves in Costa Rica. Indoor Air 2003; 13:253-59.

4. Ezzati M, Lopez AD, Rogers A, Vander Hoorn S, Murray CJL. Selected Major Risk Factors and Global and Regional Burden of Disease. Lancet 2002;360:1347-60.

5. Kmucha ST. Indoor Air Pollution and Health. Available At www.indoorairpollutionandhealth.mht Last Accessed 23/05/2008.

6. Zhou BS, Wang TJ, Guan P, Wu JM. Indoor Air Pollution and Pulmonary Adenocarcinoma Among Females:A Case- Control Study in Shenyang, China. Oncol Rep 2000; 7:1253-59.

7. Suchecki PMJ. How to Fight Indoor Air Pollution. A v a i a b e a t . L a s t A c c e s e d 15/08/2008.eHow_com.mht.

8. Akunne AF, Kyobutungi C, Sauerborn R. Re: Lung Cancer and Indoor Pollution From Heating and Cooking With Solid Fuels: the IARC International Multicenter Case- Control Study in Eastern/ Central Europe and the United Kingdom. Am J Epidemiol 2006; 163:392.

9. Plateau State. From Wikipedia, The Free Encyclopedia.

10. WHO Plateau State Total Population By Ward 2008.

11. Methanol Stoves for Indoor Air Pollution Reduction In Delta State, Nigeria. Available at www. Indoorairpollutionnigeria.com. Last Accessed 14/07/2008. 
12. World Resources Institute, UNEP, UNDP, World Bank.199899 World Resources: A Guide to the Global Environment.

13. Oliver LC, Shackleton BW. The Indoor Air We Breathe. Public Health Reports, 11(5):398409, 1998 Sept-Oct.

14. National Family Health Survey (1995) National Family Health Survey (MCH and Family Planning): India, 199293 (International Institute for Population Sciences, Bombay).

15. Obueh, J. Boiling Point 47: Using a household energy technology to promote small scale enterprises in rural communities in Nigeria The egaga stove experience.

16. World Health Organization. Indoor Air Pollution and Health. Available at WHO_indoorairpollution.htm. Last Accessed 17/08/2008.
17. Collings DA, Sithole SD, Martin KS. Indoor Wood Smoke Pollution Causing Lower Respiratory Disease in Children. Tropical Doctor, 2000, 20: 151155.

18. Norboo T. Domestic Pollution and Respiratory Illness in a Himalayan Village. International Journal of Epidemiology, 2001, 20: 749757.

19. Robin LF. Wood-burning Stoves and Lower Respiratory Illnesses in Navajo Children. Pediatric Infectious Diseases Journal, 200, 15: 859865.

20. Agnihotram V. Ramanakumar, Chattopadyay A: Respiratory Disease Burden In Rural India: A Review From Multiple Data Sources. The Internet Journal of Epidemiology. 2005;2:2 